\title{
Effect of Biofield Energy Treatment on Physical and Structural Properties of Calcium Carbide and Praseodymium Oxide
}

\author{
Mahendra Kumar Trivedi ${ }^{1}$, Rama Mohan Tallapragada ${ }^{1}$, Alice Branton ${ }^{1}$, Dahryn Trivedi ${ }^{1}$, \\ Gopal Nayak ${ }^{1}$, Omprakash Latiyal ${ }^{2}$, Snehasis Jana ${ }^{2, *}$ \\ ${ }^{1}$ Trivedi Global Inc., Henderson, USA \\ ${ }^{2}$ Trivedi Science Research Laboratory Pvt. Ltd., Bhopal, Madhya Pradesh, India
}

Email address:

publication@trivedisrl.com (S. Jana)

\section{To cite this article:}

Mahendra Kumar Trivedi, Rama Mohan Tallapragada, Alice Branton, Dahryn Trivedi, Gopal Nayak, Omprakash Latiyal, Snehasis Jana. Effect of Biofield Energy Treatment on Physical and Structural Properties of Calcium Carbide and Praseodymium Oxide. International Journal of Materials Science and Applications. Vol. 4, No. 6, 2015, pp. 390-395. doi: 10.11648/j.ijmsa.20150406.14

\begin{abstract}
Calcium carbide $\left(\mathrm{CaC}_{2}\right)$ is known for its wide applications in the production of acetylene and calcium cyanamide, whereas praseodymium Oxide $\left(\mathrm{Pr}_{6} \mathrm{O}_{11}\right)$ is used in sensors and high-temperature pigments. The present study was designed to evaluate the effect of biofield energy treatment on the physical and structural properties ${ }^{2} \mathrm{CaC}_{2}$ and $\operatorname{Pr}_{6} \mathrm{O}_{11}$ powder. The powder samples of both compounds were equally divided into two parts, referred as control and treated. The treated part of both compounds was subjected to Mr. Trivedi's biofield energy treatment. After that, both control and treated samples were investigated using X-ray diffraction (XRD) and Fourier transform infrared (FT-IR) spectroscopy. The XRD data revealed that the biofield energy treatment has increased the lattice parameter of unit cell by $3.35 \%$ in the treated $\mathrm{CaC}_{2}$ sample as compared to the control. The density of treated $\mathrm{CaC}_{2}$ sample was reduced upto $4.49 \%$ and molecular weight was increased upto $4.70 \%$ as compared to the control. The crystallite size of $\mathrm{CaC}_{2}$ was reduced from $98.19 \mathrm{~nm}$ (control) to $52.93 \mathrm{~nm}$ in the treated $\mathrm{CaC}_{2}$ sample as compared to the control. The FT-IR analysis exhibited that the absorption band attributed to $\mathrm{C}=\mathrm{C}$ stretching vibration was shifted to higher wavenumber as compared to the control. Thus, above data suggested that biofield energy treatment has considerable impact on the physical and structural properties of $\mathrm{CaC}_{2}$. Besides, in $\operatorname{Pr}_{6} \mathrm{O}_{11}$, the XRD did not show any significant change in lattice parameter, density and molecular weight. However, the FT-IR spectra revealed that the absorption band attributing to $\mathrm{Pr}-\mathrm{O}$ stretching vibration was shifted from $593 \mathrm{~cm}^{-1}$ (control) to higher wavenumber $598 \mathrm{~cm}^{-1}$ in the treated $\operatorname{Pr}_{6} \mathrm{O}_{11}$ sample. Therefore, the biofield energy treatment could be applied to modify the $\mathrm{CaC}_{2}$ and $\operatorname{Pr}_{6} \mathrm{O}_{11}$ powder for the use in chemical industries.
\end{abstract}

Keywords: Calcium Carbide, Praseodymium Oxide, Biofield Energy Treatment, X-Ray Diffraction, Fourier Transform Infrared Spectroscopy

\section{Introduction}

Calcium carbide is an important industrial material, used in the production of acetylene and cyanamide [1]. It is a colorless solid, exist in the form of a distorted rock-salt structure with the $\mathrm{C}_{2}{ }^{2-}$ units lying parallel [2]. It gains significant attention due to its use in the desulfurization of steel and cast iron in steel industries. It acts as a fuel in steelmaking to extend the scrap ratio to liquid iron [3]. In addition, it plays an important role in artificial ripening of fruit, which provides the acetylene gas similar to ethylene
[4]. It is synthesized from a mixture of lime and coke in electric arc furnace at very high temperature approximately $2000^{\circ} \mathrm{C}$ [5]. Due to high temperature, it is difficult to control the physical and structural properties of $\mathrm{CaC}_{2}$ using conventional methods. Thus, it is important to find a suitable approach which can modify the physical and structure properties of $\mathrm{CaC}_{2}$, after synthesis from convention methods.

Over the past few years, praseodymium oxide $\left(\operatorname{Pr}_{6} \mathrm{O}_{11}\right)$ has been utilized in different applications such as high-temperature pigments [6], and catalysts [7, 8]. It is also used in sensors and oxygen storage components of three-way automotive catalysts [9]. Currently, it is synthesized by various processes such as 
solid-state reactions [10-12], a molten salt method [13], or solgel [14]. However, these processes have certain limitation such as large crystallite size, non-uniformity, etc. Furthermore, in order to use these compounds in industries, its physical and structural properties play a crucial role. Thus, it is important to avail an alternative approach i.e. biofield energy treatment, which may be used to modify the physical and structural properties of $\mathrm{CaC}_{2}$ and $\operatorname{Pr}_{6} \mathrm{O}_{11}$ powder.

It is well established that the energy can be transferred from one place to another place using several scientific techniques. Further, it exists in various forms such as thermal, electric, kinetic, nuclear, etc. The living organisms are exchanging their energy with the environment for their health maintenance [15]. Moreover, a human has the capability to harness the energy from the environment/Universe and transmit it to any object around the Globe. The object(s) receive the energy and respond in a useful way that is called biofield energy, and this process is known as biofield energy treatment. The National Center for Complementary and Alternative Medicine (NCCAM) has recommended the use of alternative CAM therapies (e.g. healing therapy) in the healthcare sector [16]. Moreover, Mr. Trivedi's unique biofield energy treatment (The Trivedi Effect ${ }^{\circledR}$ ) had been extensively studied in materials science $[17,18]$. It has substantially altered the atomic, physical and thermal properties in metals [18, 19] and ceramics [20]. Thus, after considering the effect of biofield energy treatment on metals and ceramics, this study was designed to evaluate the effect of this treatment on the physical and structural properties of the $\mathrm{CaC}_{2}$ and $\operatorname{Pr}_{6} \mathrm{O}_{11}$ powder using X-ray diffraction (XRD) and Fourier transform infrared (FT-IR) spectroscopy.

\section{Materials and Methods}

The $\mathrm{CaC}_{2}$ and $\operatorname{Pr}_{6} \mathrm{O}_{11}$ powder were purchased from Sigma Aldrich, USA. Each powder samples were divided into two groups: control and treated. The control sample of both compound were remained as untreated, while the treated samples were in sealed pack, handed over to Mr. Trivedi for biofield energy treatment under standard laboratory condition. Mr. Trivedi provided the treatment through his energy transmission process to the treated samples without touching the samples. The control and treated samples were analyzed using XRD and FT-IR.

\subsection{XRD Study}

The Phillips, Holland PW 1710 X-ray diffractometer system was used to perform the XRD analysis of control and treated samples. From the XRD system, the data was obtained in the form of a table containing Bragg angles, the peak intensity counts, relative intensity $(\%), d$-spacing value $(\AA)$, and full width half maximum (FWHM) $\left(\theta^{\circ}\right)$ for each peak. After that, the PowderX software was used to calculate the crystal structure parameters such as lattice parameter and unit cell volume of the control and treated samples. Also, the Scherrer equation was used to compute the crystallite size as given below:

$$
\text { Crystallite size }(G)=\frac{k \lambda}{b \cos \theta}
$$

Here, $\mathrm{k}$ is equipment constant $(=0.94), \lambda=1.54056 \AA$, and $\mathrm{b}$ is full width half maximum (FWHM). After that, the percentage change in $G$ was calculated using following formula:

Percent change in crystallite size $(G)=\frac{G_{t}-G_{c}}{G_{c}} \times 100$

Where, $G_{c}$ and $G_{t}$ are the crystallite size of control and treated samples, respectively.

\subsection{FT-IR Spectroscopy}

The FT-IR analysis of control and treated samples were accomplished on Shimadzu's Fourier transform infrared spectrometer (Japan). The spectra was obtained with frequency range of $4000-500 \mathrm{~cm}^{-1}$. The purpose of the FT-IR analysis was to study the impact of biofield energy treatment on dipole moment, force constant and bond strength in the compounds

\section{Results and Discussion}

\subsection{XRD Study}

The XRD technique is a quantitative and non-destructive technique, which is commonly used to study the crystal structure and related parameters of a compound. Fig. 1 shows the XRD diffractograms of control and treated $\mathrm{CaC}_{2}$ samples. The control $\mathrm{CaC}_{2}$ sample showed the intensive XRD peaks at Bragg's angle (20) $26.57^{\circ}, 27.95^{\circ}, 32.51^{\circ}$, and 37.34 which were supported by the literature [21]. However, the treated $\mathrm{CaC}_{2}$ sample $\mathrm{T} 1$ exhibited the crystalline peaks at Bragg's angle $27.24^{\circ}, 28.39^{\circ}, 32.10^{\circ}, 34.00^{\circ}$, and $37.27^{\circ}$. Furthermore, the treated sample T2 showed the peaks at $33.04^{\circ}, 34.77^{\circ}, 38.18^{\circ}$, and 44.61. Thus, above data suggested that the positions of the peaks in the treated samples were significantly altered as compared to the control. The alteration in peak positions in treated samples could be due to the energy transferred through biofield energy treatment. It is possible that the energy transferred through treatment induced stress, which may generate internal strain in the treated samples and that might be responsible for the alteration in peak positions in the treated samples as compared to the control. Besides, the crystal structure parameters of both control and treated $\mathrm{CaC}_{2}$ samples were computed using PowderX software and presented in Table 1. The data exhibited that the lattice parameter of unit cell was changed from $8.36 \AA$ (control) to $8.32 \AA$ and $8.64 \AA$ in treated $\mathrm{CaC}_{2}$ samples $\mathrm{T} 1$ and $\mathrm{T} 2$, respectively. It indicated that the lattice parameter was increased by $3.35 \%$ in $\mathrm{T} 2$, though no significant change was found in $\mathrm{T} 1$ as compared to the control (Fig. 2). The data also showed that the unit cell volume was increased by 1.83 and 
$4.70 \%$ in $\mathrm{T} 1$ and $\mathrm{T} 2$, respectively as compared the control. The increase in unit cell volume led to reduce the density by 1.80 and $4.49 \%$ in $\mathrm{T} 1$ and $\mathrm{T} 2$, respectively as compared the control. On the contrary, the molecular weight was increased by 1.83 and $4.7 \%$ in $\mathrm{T} 1$ and $\mathrm{T} 2$, respectively as compared to the control. Thus, the above results suggested that the biofield energy treatment probably acted at nuclear level to cause these modifications. It is assumed that the energy transferred through biofield treatment could be in the form of the neutrinos, which probably acted at nuclear level to cause these modifications at nuclear level. Besides, it was also observed that the crystallite size was reduced from $98.19 \mathrm{~nm}$ (control) to $74.35 \mathrm{~nm}$ and $52.93 \mathrm{~nm}$ in $\mathrm{T} 1$ and $\mathrm{T} 2$ samples, respectively. It was reported that presence of internal strain leads to fracture the crystallite into sub-crystallites [22]. Thus, it assumed that internal strain induced through biofield energy treatment led to reduce the crystallite size in treated $\mathrm{CaC}_{2}$ samples. It is known that the $\mathrm{CaC}_{2}$ is widely used in the production of acetylene gas in industries. In this process, $\mathrm{CaC}_{2}$ reacts with water to form acetylene gas; thus for this chemical reaction the surface area and crystallite size of $\mathrm{CaC}_{2}$ play an important role [23]. It was reported that the decrease in crystallite size led to increase the surface area and increase the chemical reactivity [24]. Thus, based on this, it is assumed that the decrease in crystallite size in treated $\mathrm{CaC}_{2}$ may increase the rate of the reaction for the production of acetylene gas and that may resulted into higher yield as compared to the control.
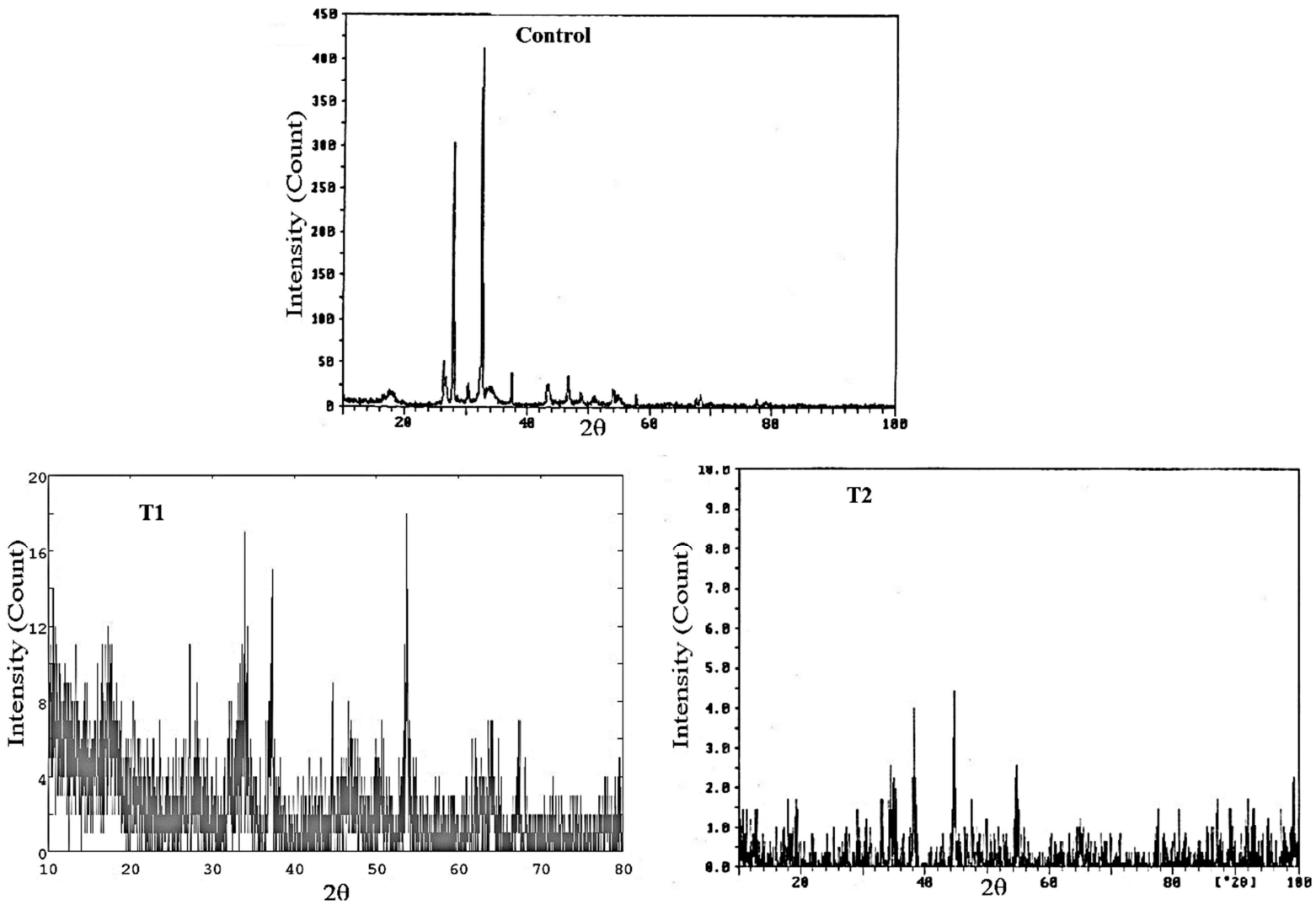

Fig. 1. X-ray diffractogram of calcium carbide powder.

The XRD diffractogram of control and treated $\operatorname{Pr}_{6} \mathrm{O}_{11}$ samples is presented in Fig. 3. It shows the intensive XRD

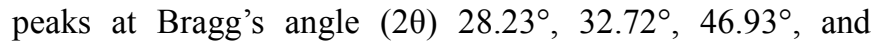
$55.68^{\circ}$, which were corresponded to crystalline planes (111), (200), (220), and (311), respectively according to the joint committee on powder diffraction standards (JCPDS) card no. 42-1121 [25]. However, the treated sample showed the peaks at $28.25^{\circ}, 32.71^{\circ}, 46.96^{\circ}$, and $55.72^{\circ}$. Thus, data suggested that the peaks position were slightly altered due to biofield energy treatment. Moreover, the lattice parameter, unit cell volume, density and molecular weight did not show any significant changes in treated sample as compared to the control.

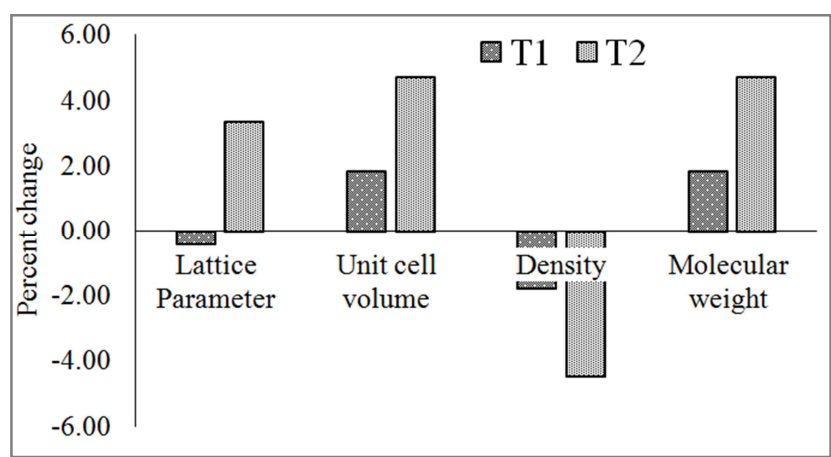

Fig. 2. Effect of biofield energy treatment on lattice parameter, unit cell volume, density, and molecular weight of calcium carbide. 

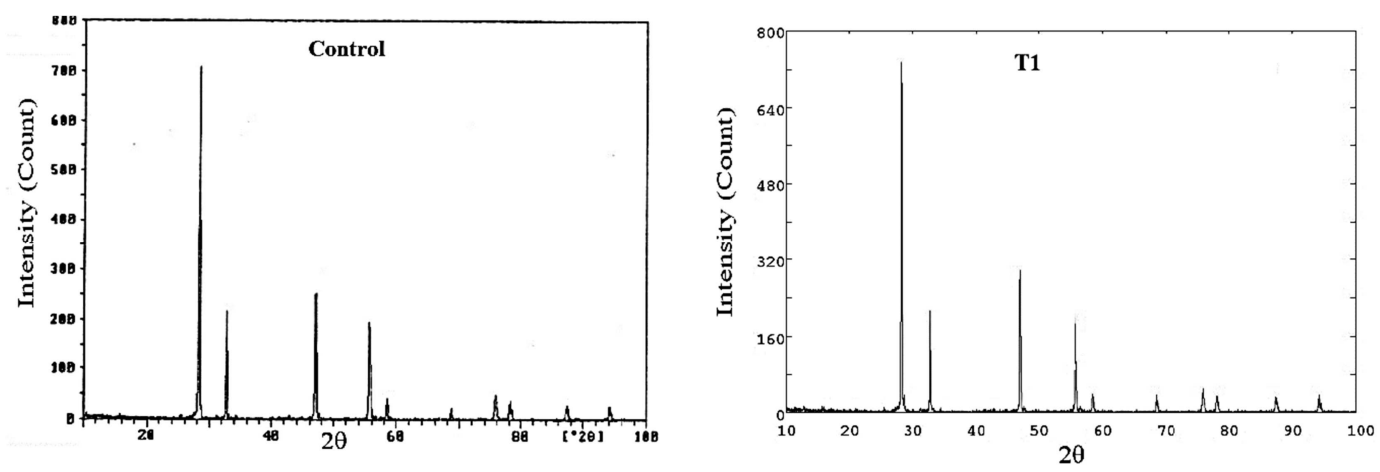

Fig. 3. X-ray diffractogram of praseodymium oxide powder.

Table 1. The crystal structure parameter calcium carbide and praseodymium oxide powder.

\begin{tabular}{lllllll}
\hline Compound & Group & Lattice parameter $(\boldsymbol{\AA})$ & Unit cell volume $\left(\times \mathbf{1 0}^{-\mathbf{2 3}} \mathbf{c m}^{\mathbf{3}}\right)$ & Density $(\mathbf{g} / \mathbf{c c})$ & Molecular weight $(\mathbf{g} / \mathbf{m o l})$ & Crystallite size $(\mathbf{n m})$ \\
\hline \multirow{2}{*}{$\mathrm{CaC}_{2}$} & Control & 8.36 & 38.45 & 2.23 & 64.55 & 98.19 \\
& $\mathrm{~T} 1$ & 8.32 & 39.15 & 2.19 & 65.73 & 74.35 \\
& $\mathrm{~T} 2$ & 8.64 & 40.26 & 2.13 & 67.58 & 52.93 \\
$\mathrm{Pr}_{6} \mathrm{O}_{11}$ & Control & 5.47 & 16.37 & 6.98 & 1030.85 & 71.09 \\
\hline
\end{tabular}
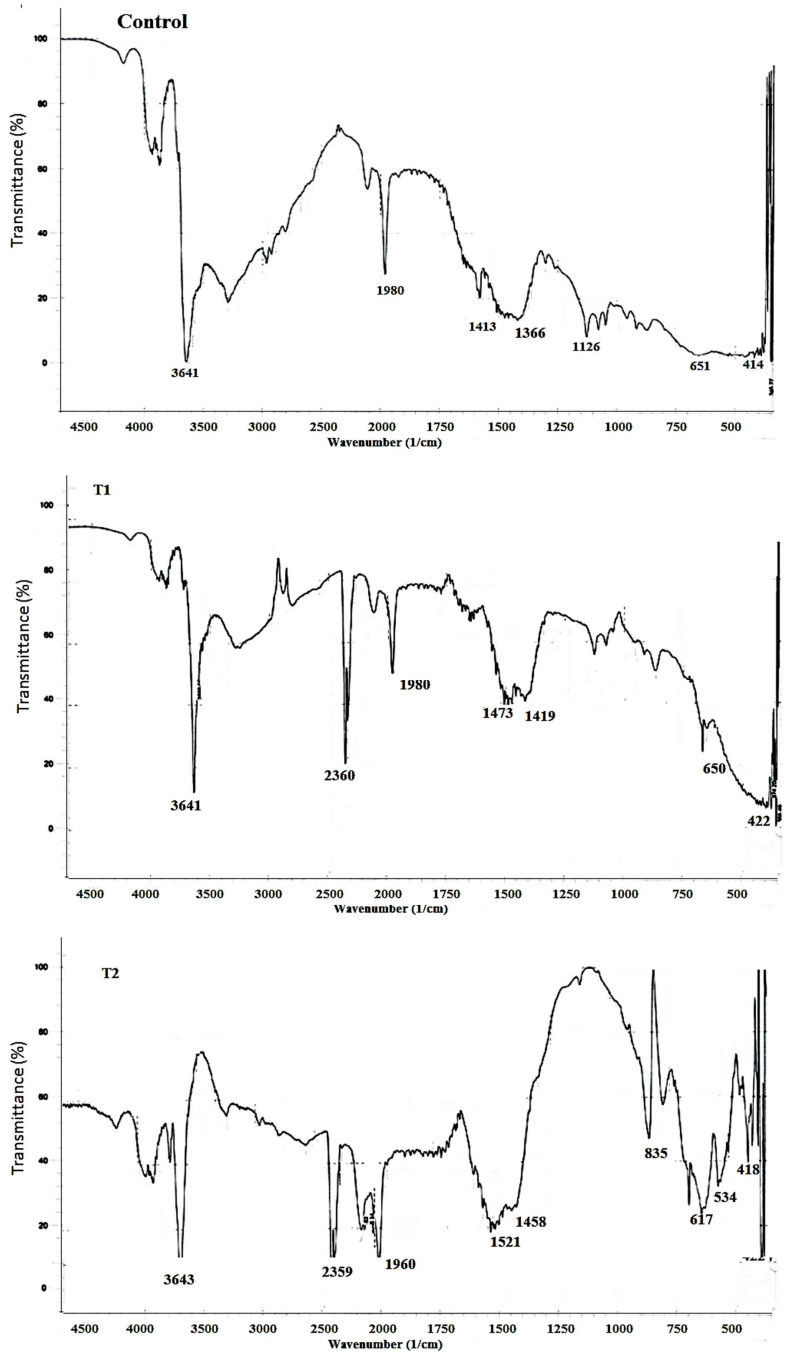

Fig. 4. FT-IR spectra of calcium carbide powder.

\subsection{FT-IR Spectroscopy}

The FT-IR spectra of control and treated $\mathrm{CaC}_{2}$ samples are presented in Fig. 4. It showed the absorption bands at 3641 $\mathrm{cm}^{-1}, 3641 \mathrm{~cm}^{-1}$ and $3643 \mathrm{~cm}^{-1}$ in control, T1, and T2, respectively, which can be attributed to $-\mathrm{OH}$ stretching vibration. The emergence of these peak could be due to moisture absorption by the sample. Further, doublet found at 1413 and 1366 in control was due to $\mathrm{C}=\mathrm{C}$ stretching vibrations, however, it was shifted to $1473 \mathrm{~cm}^{-1}$ and $1419 \mathrm{~cm}^{-}$ ${ }^{1}$ in $\mathrm{T} 1$; and $1521 \mathrm{~cm}^{-1}$ and $1458 \mathrm{~cm}^{-1}$ in T2 sample [26]. In addition, the absorption peak attributing to $\mathrm{Ca}-\mathrm{C}$ bond was found at $414 \mathrm{~cm}^{-1}$ (control) that was shifted to higher wavenumber $422 \mathrm{~cm}^{-1}$ and $418 \mathrm{~cm}^{-1}$ in $\mathrm{T} 1$ and $\mathrm{T}$, respectively.

It was reported that the wavenumber $(\bar{v})$ is directly related to the bond force constant $(\mathrm{k})$ as following [27]:

$$
\bar{v}=\frac{1}{2 \pi c} \sqrt{\frac{k}{\mu}}
$$

Here, $\mu$ is the effective mass of atoms, which form the bond and $\mathrm{c}$ is the speed of light $\left(3 \times 10^{8} \mathrm{~m} / \mathrm{s}\right)$. The equation inferred that the increase in bond force constant can lead to shift the absorption wavenumber toward higher side. Previously, our group reported that biofield energy treatment has altered the bond length of Ti-O bond in barium titanate [28]. Based on this, it is assumed that the bond force constant of $\mathrm{C}=\mathrm{C}$ bond probably increased after biofield energy treatment.

Fig. 5 shows the FT-IR spectra of control and treated $\operatorname{Pr}_{6} \mathrm{O}_{11}$ samples. The spectra shows the absorption bands at $3445 \mathrm{~cm}^{-1}$ in control and treated $\operatorname{Pr}_{6} \mathrm{O}_{11}$ sample, which can be attributed to $-\mathrm{OH}$ stretching vibration. The emergence of these peak could be due to moisture absorption by the sample 
[27]. Further, the peak observed at $593 \mathrm{~cm}^{-1}$ (control) was shifted to higher wavenumber $598 \mathrm{~cm}^{-1}$ in treated sample, which was assigned to stretching vibration Pr-O [29]. Based on equation (1), it is assumed that the biofield energy treatment possibly increased the bond force constant of Pr-O bond, due to which the peak was shifted to higher wavenumber in the treated sample as compared to the control. Further, it is possible that the energy transferred through biofield energy treatment probably acted on the atomic bonding level to cause these modifications.

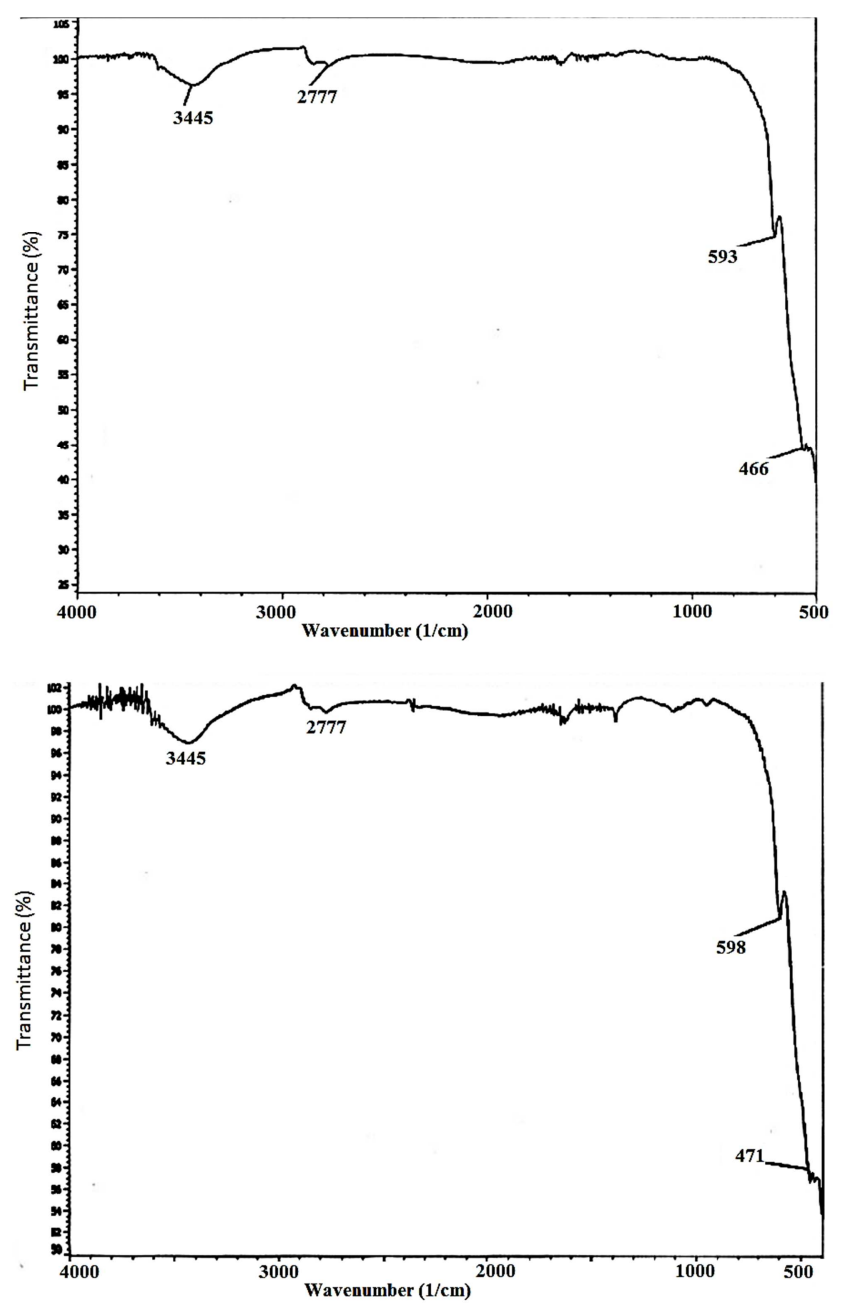

Fig. 5. FT-IR spectra of praseodymium oxide powder.

\section{Conclusions}

The XRD data revealed that the biofield energy treatment has increased the lattice parameter of unit cell by $3.35 \%$ in treated $\mathrm{CaC}_{2}$ sample as compared to the control. The density of treated $\mathrm{CaC}_{2}$ sample was reduced upto $4.49 \%$ and molecular weight was increased upto $4.70 \%$ as compared to the control. The crystallite size of $\mathrm{CaC}_{2}$ was reduced from $98.19 \mathrm{~nm}$ (control) to $52.93 \mathrm{~nm}$ in treated $\mathrm{CaC}_{2}$ sample as compared to the control. The decrease in crystallite size in treated sample may enhance the reactivity of $\mathrm{CaC}_{2}$ in the production of acetylene gas. The FT-IR analysis exhibited that the absorption band attributed to $\mathrm{C}=\mathrm{C}$ stretching vibrations was shifted to higher wavenumber as compared to the control. Thus, above data suggested that biofield energy treatment has considerable impact on the physical and structural properties of $\mathrm{CaC}_{2}$. Besides, in $\operatorname{Pr}_{6} \mathrm{O}_{11}$, the XRD did not show any significant changes in lattice parameter, density and molecular weight after biofield treatment. However, the FT-IR revealed that the absorption band attributing to Pr-O stretching vibration was shifted from $593 \mathrm{~cm}^{-1}$ (control) to higher wavenumber $598 \mathrm{~cm}$ ${ }^{1}$ in the treated $\operatorname{Pr}_{6} \mathrm{O}_{11}$ sample. Therefore, the biofield energy treatment could be applied to modify the physical and structural properties of $\mathrm{CaC}_{2}$ and $\operatorname{Pr}_{6} \mathrm{O}_{11}$ powder for the use chemical industries respectively.

\section{Acknowledgments}

Authors would like to acknowledge Dr. Cheng Dong of NLSC, Institute of Physics, and Chinese academy of sciences for supporting in analyzing the XRD data using Powder-X software. The authors would also like to thank Trivedi Science, Trivedi Master Wellness and Trivedi Testimonials for their support during the work.

\section{References}

[1] Paizullakhanov MS, Faiziev SA (1998) Solid-phase synthesis of calcium carbide in a plasma reactor. Plasma Chem Plasma Process 18: 409-427.

[2] Greenwood NN, Earnshaw A (1997). Chemistry of the Elements. (2ndedn), Butterworth-Heinemann.

[3] Arh B, Vode F, Tehovnik F, Burja J(2015) Reduction of chromium oxides with calcium carbide during the stainless steelmaking process. Metalurgija 54: 368-370.

[4] Abeles FB, Gahagan HE (1968) Abscission: The role of ethylene, ethylene analogues, carbon dioxide, and oxygen. Plant Physiol 43: 1255-1258.

[5] Morehead JT, de Chalmot G (1896) The manufacture of calcium carbide. J Am Chem Soc 18: 311-331.

[6] Sulcova $\mathrm{P}$ (2005) Thermal synthesis of the $\mathrm{CeO}_{2}-\mathrm{PrO}_{2}-\mathrm{Nd}_{2} \mathrm{O}_{3}$ pigments. J Therm Anal Calorim 82: 51-54.

[7] Asami K, Kusakabe K-I, Ashi N, Ohtsuka Y (1997) Synthesis of ethane and ethylene from methane and carbon dioxide over praseodymium oxide catalysts. Appl Catal A: General 156: 4356.

[8] Bernal S, Botana FJ, Cifredo G, Calvino JJ, Jobacho A, et al. (1992), Preparation and characterization of a praseodymium oxide to be used as a catalytic support. J Alloys Compd 180: 271-279.

[9] Kawabe M, Ono H, Sano T, Tsuji M, Tamaura Y (1997) Thermochemical oxygen pump with praseodymium oxides using a temperature-swing at 403-873 K. Energy 22: 10411049 .

[10] Huang PX, Wu F, Zhu BL, Li GR, Wang YL, et al. (2006) Praseodymium hydroxide and oxide nanorods and $\mathrm{Au} / \mathrm{Pr}_{6} \mathrm{O}_{11}$ nanorod catalysts for $\mathrm{CO}$ oxidation, J Phys Chem B 110: 1614-1620. 
[11] Ma L, Chen W, Zhao J, Zheng Y, Li X, et al. (2007) Microwave-assisted synthesis of praseodymium hydroxide nanorods and thermal conversion to oxide nanorod. Mater Lett 61: 1711-1714.

[12] Matovic B, Pantic J, Prekayski M, Stankovic N, Bucevac D, et al. (2013) Synthesis and characterization of $\operatorname{Pr}_{6} \mathrm{O}_{11}$ nanopowders. Ceram Int 39: 3151-3155.

[13] Wang X, Zhuang J, Li YD (2004) $\operatorname{Pr}_{6} \mathrm{O}_{11}$ Single-crystal nanotubes from a molten-salt synthetic method. Eur J Inorg Chem 5: 946-948.

[14] Hassan MS, Kang YS, Kim BS, Kim IS, Kim H, et al. (2011) Synthesis of praseodymium oxide nanofiber by electrospinning. Superlatt and microstruct 50: 139-144.

[15] Saad M, Medeiros RD (2012) Distant healing by the supposed vital energy- scientific bases. Complementary therapies for the contemporary healthcare. InTech.

[16] Barnes PM, Powell-Griner E, McFann K, Nahin RL (2004) Complementary and alternative medicine use among adults: United States, 2002. Adv Data 343: 1-19.

[17] Trivedi MK, Patil S, Nayak G, Jana S, Latiyal O (2015) Influence of biofield treatment on physical, structural and spectral properties of boron nitride. J Material Sci Eng 4: 181.

[18] Trivedi MK, Nayak G, Patil S, Tallapragada RM, Latiyal O et al. (2015) An evaluation of biofield treatment on thermal, physical and structural properties of cadmium nanopowder. J Thermodyn Catal 6: 147.

[19] Trivedi MK, Tallapragada RM, Branton A, Trivedi D, Nayak $\mathrm{G}$, et al. (2015) Potential impact of biofield treatment on atomic and physical characteristics of magnesium. Vitam Miner 3: 129.

[20] Trivedi MK, Nayak G, Patil S, Tallapragada RM, Latiyal O (2015) Studies of the atomic and crystalline characteristics of ceramic oxide nano nanopowders after bio field treatment. Ind Eng Manage 4: 161.

[21] Pillai RC, Sabolsky E, Rowan SL, Celik I, Morrow S (2015) Solid state synthesis of calcium carbide by using $2.45 \mathrm{GHz}$ microwave reactor. Ind Eng Chem Res 54: 11001-11010.

[22] Trivedi MK, Tallapragada RM (2008) A transcendental to changing metal powder characteristics. Met Powder Rep 63: $22-28,31$.

[23] Kelter PB, Mosher MD, Scott A (2008) Chemistry: The Practical Science. Cengage Learning.

[24] Naidu SM (2012) Engineering Physics. Pearson Education India.

[25] Abu-Zied BM, Mohamed YA, Asiri Am (2013) Fabrication, characterization, and electrical conductivity properties of $\operatorname{Pr}_{6} \mathrm{O}_{11}$ nanoparticles. J Rare Earths 31: 701-708.

[26] Bushiri MJ, Kosugi K, Nishi N (2004) Structure and magnetic properties of transition metal acetylide compounds MC2 (M = $\mathrm{Mn}, \mathrm{Fe}, \mathrm{Co}$ and $\mathrm{Ni}$ ).

[27] Ghosh M, Dilawar N, Bandyopadhyay AK, Raychaudhuri AK (2009) Phonon dynamics of $\mathrm{Zn}(\mathrm{Mg}, \mathrm{Cd}) \mathrm{O}$ alloy nanostructures and their phase segregation. J Appl Phys 106: 1-6.

[28] Trivedi MK, Nayak G, Patil S, Tallapragada RM, Latiyal O, et al. (2015) Impact of biofield treatment on atomic and structural characteristics of barium titanate nanopowder. Ind Eng Manage 4: 166.

[29] Abdullah WRW, Zakaria A, Ghazali MSM (2012) Synthesis mechanism of low-voltage praseodymium oxide doped zinc oxide varistor ceramics prepared through modified citrate gel coating. Int J Mol Sci 13: 5278-5289. 